\title{
A retrospective evaluation of acute kidney injury and effects of renal replacement therapy in septic or nonseptic critically ILL patients
}

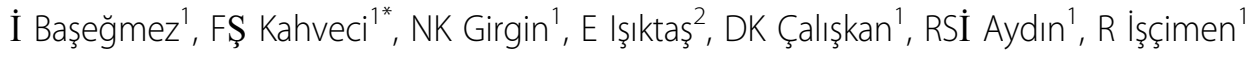 \\ From ESICM LIVES 2015 \\ Berlin, Germany. 3-7 October 2015
}

\section{Intr}

Acute kidney injury (AKI) is characterized with decline in the glomerular filtration rate, elevation of serum blood urea nitrogen, creatinine, and other metabolic waste products [1]. AKI is considered to be associated with sepsis between 45 to $70 \%$ [2].

\section{Objectives}

The aim of the study was to investigate the variabilities in vital signs, hemodynamic parameters and laboratory values after receiving renal replacement therapy (RRT) among AKI patients with or without sepsis in intensive care unit (ICU). Also we examined the two different renal injury staging systems in the patients.

\section{Methods}

After obtaining approval from the Ethics Committee, patients who were admitted to ICU between 01.01.2010 - 30.06.2014 and requiring RRT in the management of AKI were enrolled. They were divided into septic shock group or nonseptic group. Glasgow coma score (GCS), vital signs, laboratory values, vasopressor or inotropic agents requirements at initiation, $12^{\text {th }}$ and $24^{\text {th }}$ hours of RRT were collected. APACHE II scores, $28^{\text {th }}$ and $90^{\text {th }}$ day mortality were also recorded. Staging of AKI was carried out based on KDIGO 2012 guidelines and RIFLE (Risk, Injury, Failure, Loss of kidney function and Endstage renal failure).

\section{Results}

A total of 153 patients were included in the study. Ninety three patients had septic shock. APACHE II

\footnotetext{
'University of Uludag, School of Medicine, Anesthesiology and ICU, Bursa, Turkey

Full list of author information is available at the end of the article
}

score and $28^{\text {th }}$ day mortality were significantly higher in Group Septic Shock ( $<<0.001, \mathrm{p}<0.001$ respectively). In subjects above 62 years of age found associated with higher $90^{\text {th }}$ day mortality $(\mathrm{p}=0.002)$.

Both in two groups glomerular filtration rates, urea and creatinine levels improved after RRT initiation ( $\mathrm{p}<$ 0.001). Also inotropic and vasopressor agent using has decreased significantly after RRT in both groups ( $\mathrm{p}<$ 0.001).

Frequency of AKI were comparable with the KDIGO guideline and RIFLE classification ( $\mathrm{p}=0,5, \mathrm{p}=0,5$ respectively).

\section{Conclusions}

Mortality rate increases when AKI complicated with sepsis and higher age. The KDIGO staging for AKI is equivalent to the RIFLE classification in septic or nonseptic critically ill patients.

\section{Authors' details}

'University of Uludag, School of Medicine, Anesthesiology and ICU, Bursa, Turkey. ${ }^{2}$ University of Uludag, School of Medicine, Nephrology and Internal Medicine, Bursa, Turkey.

\section{Published: 1 October 2015}

\section{References}

1. Lerma E, Berns JS, Nissenson A: Current Diagnosis \& Treatment Nephrology \& Hypertension. $1^{\text {st }}$ edition. United States of America. McgrawHill Companies 2009, 453-62.

2. Bagshaw SM, et al: Septic acute kidney injury in critically ill patients: Clinical characteristics and outcomes. Clin J Am Soc Nephrol 2007, 2:431-9.

doi:10.1186/2197-425X-3-S1-A265

Cite this article as: Başeğmez et al:: A retrospective evaluation of acute kidney injury and effects of renal replacement therapy in septic or nonseptic critically ILL patients. Intensive Care Medicine Experimental 2015 3(Suppl 1):A265.

\section{SpringerOpen $^{\odot}$}

(c) 2015 Kahveci et al.; This is an Open Access article distributed under the terms of the Creative Commons Attribution License (http:// creativecommons.org/licenses/by/4.0), which permits unrestricted use, distribution, and reproduction in any medium, provided the original work is properly cited. 